\title{
THE INFLUENCE OF PRICE AND LOCATION AGAINST THE DECISION OF BUYING A HOME IN PT WIRATAMA GROUP UNIT GRAND MANSION JOHOR MEDAN
}

\author{
Nadia Ika Purnama ${ }^{1}$, Raja Tia Parama Arta ${ }^{2}$ \\ Faculty of Economic and Business Universitas Muhammadiyah Sumatera Utara \\ nadiaika96@gmail.com ${ }^{1}$, radjathea@yahoo.co.id ${ }^{2}$
}

\begin{abstract}
Consumer purchasing decisions is an act committed a consumer to buy a product. Every manufacturer is definitely running a variety of strategies to let consumers decide to buy its products. Purchase decisions arising from the existence of objective research or due to the encouragement of emotions. The decision to act was the result of a series of emotional activity and mental stimulation. Purchasing decisions can be influenced by two factors such as Price and location. This research aims to know the influence of the price and the location of the home in pt. Wiratama Group Unit Grand Mansion Johor Medan. The population in this research is all customers PT. Wiratama Group with Field samples as many as 100 people using the quota sampling. This data collection techniques with interviews (interview) questionnaire and then test the validity and reliability of the test. Data analysis technique used is a classic assumption test, multiple regression, $t$-test, $F$-test, and the coefficient of determination (R-Square). The research results showed that prices significantly to influential buying decision with 4,263 thitung > 1,660 t tabel and the value of sig is $0.000<0.05$. significantly to influential Locations Purchasing Decisions with 3,968 thitung > 1,660 t tabel with the value of the sig is $0.000<0.05$. Based on test results obtained $F$ value simultaneously significantly to influential buying decision. The $R$-Square value determination of $53.6 \%$ shows the purchase decisions influenced by price and Location and the remaining $46.4 \%$ influenced other variables not examined.
\end{abstract}

Keywords: Price, Location, Purchase Decisions, Consumer and Strategies

\section{INTRODUCTION}

Increased population growth became one of the factors of increasing housing demand. The need for a home is one of the basic needs of people after food and clothing. Every human individual will prioritize the fulfillment of basic needs rather than secondary needs. Similarly with the needs of the house, everyone will try to meet the needs of the house in every level of community life with attention to taste and abilities that exist.

PT. Wiratama Group is engaged as a service agent and property consultant who became the media solutions of various property development business. In its journey, PT. Wiratama Group has grown by having concepts, solutions and strategies as well as being directly involved in handling entrusted projects. Along with the passage of time, PT. Wiratama Group continues to grow and expand in the number of experienced personnel in the property world, and continue to improve the quality of its human resources through education and interaction forums. With the quality of human resources professional, PT. Wiratama Group can be trusted in developing and handling projects in the property sector.

In the beginning the house is aimed at satisfying the needs of human life for a comfortable, safe and quiet place to live. However, the current home ownership is not only intended to meet the basic needs of the board only, but has become an attractive alternative shares with the return of rental income or profit opportunities in the form of capital gains which is the difference between the purchase price and the sale price when the house is sold .

As more housing demand creates more and more new housing, competition will become increasingly difficult and developers will seek to improve the quality and service of housing such as strategic location, secure privacy security condition and complete facilities and facilities. Ease of access, complete facilities, focused development, price offered and location are a string of consumer criteria if you want to buy a home. 
Many housing built from the access side may be adequate, but in terms of facilities are still not sufficient. Completeness of facilities ultimately affect the selling value of a dwelling, the existence of complete environmental facilities to make the area become "alive" and will become a magnet for residents in the area around.

According to Misbahudin (2009, p. 23), in line with the needs of the human inhabitants, a house must fulfill its three main functions:

1. House as a residence, where one lives (settled) and get physical and mental calm.

2. House is a mediation between man and the world. With this mediation a dialogue exists between man and his world. From the crowds of the human world withdraws into his home and lives in an atmosphere of calmness, to then out again to the outside world to work and work. So on and so happens again and again.

3. The home is an arsenal, where man gets his strength back, after doing a tiring job.

According to Kotler (2008, p. 51), one of the keys to success is location, location begins by choosing community. This decision relies heavily on the potential for economic growth and stability, competition, the political climate, and so on. Consumer purchasing decisions are an action that consumers make to buy a product. Every manufacturer must run a variety of strategies for consumers to decide to buy their products. According to Kotler (2006, p.227) suggests that "Purchase decisions are an evaluation stage that allows consumers to rank their goods or services in their preferred ratings, whereas the evaluation will create a buying desire, so consumers will buy the goods or services they like."

\section{PURPOSE OBJECTIVES}

The purpose of article writing is to determine the effect of price and location of the house at PT. Wiratama Group Unit Grand Mansion Medan. Emphasis on price and location on embodiment rather than housing to be built by PT. Wiratama Group Unit Grand Mansion Medan.

\section{RESEARCH METHODOLOGY}

This study uses primary data sources and secondary data. Primary data obtained directly from the location of research in the form of data about respondents perception about the variables used in this study are presented in the form of a questionnaire (questioner). And secondary data obtained through supporting data obtained from the company in the form of documentation data relating to research variables. Instrumentation of data collection using interview and questionnaire. as follows:

Further questionnaires prepared are tested for feasibility through validity and reliability testing

\section{a. Validity Test}

1. The purpose of testing Validity

Validity testing is done to test the extent to which the accuracy or correctness of an instrument as a measurement tool research variables. If the instrument is valid / true then the measurement result will likely be true.

2. Statistical formula for Validity Testing

$$
=\frac{\mathrm{n} \sum \mathrm{xy}-\left(\sum \mathrm{x}\right)\left(\sum \mathrm{y}\right)}{\sqrt{\left\{\mathrm{n} \sum_{\mathrm{x}} 2-(\mathrm{nx})^{2}\right\}}\left\{\mathrm{n} \sum_{\mathrm{y}} 2-\left(\sum \mathrm{y}\right)^{2}\right\}}
$$

Information:

$\mathrm{r}=$ Correlation coefficient between variable $(\mathrm{X})$ and variable $(\mathrm{Y})$

$\mathrm{n}=$ Number of observation pairs

$\mathrm{x}=$ Instrument item scores of the independent variables

$y=$ Instrument item scores of the dependent variables 
The steps of validity testing performed include:

a. Correlates the scores of a questionnaire number with the total sector of all items

b. Determine whether or not valid data with the following criteria:

Criteria testing instrument reliability in this study are as follows:

a) If sig 2 tailed $<\alpha 0.05$ then the instrument grain is valid.

b) If sig 2 tailed $>\alpha 0.05$ then the instrument grain is invalid and must be removed.

\section{b. Realibility Test}

1. The purpose of testing reliability

Reliability testing is done to determine whether or not reliable research instruments that have been made. Reliable means the instrument can be used to measure the same object, will produce the same data. In this study, reliability calculations were performed with Cronbach Alpha tatistiks.

2. The statistical formula for realibity testing

The formula used in this research is:

$$
r=\left\{\frac{k}{(k-1)}\right\}\left[\frac{\sum \sigma \mathrm{b}^{2}}{\sigma 1^{2}}\right]
$$

Information:

$\mathrm{r}=$ Instrument Reliability

$\mathrm{k}=$ Number of questions

$\sum \sigma \mathrm{b}^{2}=$ Total variance of the item

$\sigma 1^{2}=$ Total variance

3. Criteria Testing Instrument Realibility

Criteria for instrument reliability testing are as follows:

a. If the value of the reliability coefficient> 0.60 then the instrument has good reliability.

b. If the coefficient value realibiltas $<0.60$ then the instrument has a less good realibilitas.

Technique used in this research is quantitative data analysis, that is test and analyze data and then draw conclusion from the test.

1. Classic Assumption Test

Azuar Juliandi, Dkk (2015, p 160) classical assumption test of multiple regression aims to analyze whether the regression model used in the study is the best model. The requirements of the classical assumption test include, normality test, multicolinearity test, heterokedastity, and autocorrelation test.

a) Test Data Normality

Normality test data is done to see that a data distribution is normal or not. Test normality of data is done by using the way that Kolmogrov-Smirnov used to determine the normal or not the data. Data is normal, if the Kolmogrov-Smirnov value is insignificant (Asymp, sig (2-tailed) $>\alpha 0.05$ ).

b) Test of Multicolonierity

This multicolonierity test is intended to find out whether there is a perfect intercorrelation between some of the independent variables used in the model. Multicolonierity occurs when there is a linear relationship between the independent variables involved in the model. If there is a high degree of multicoloniality, standard error regression coefficients will be greater and result in confidence interval for parameter estimation widened, thus open the possibility of error, accept the wrong hypothesis.

Classical assumption assays multikolonieritas can be executed by way of regressing the model of analysis and test the collation between independent variables by using variance inflation factor (VIF). 
The limit of the VIF is 10 and the tolerancevalue value is 0.1 . If the VIF value is greater than 10 and the tolerance value of cevalue is less than 0.1 then multi colonierity occurs.

c) Heteroscedasticity Test

Heteroscedasticity occurs when there is no standard deviation of the value of the dependent variable on each independent variable. If there are symptoms of heteroskedastisitas will cause the variation coefficient regression becomes minimum and confidence interval widen so that statistically significant test results are no longer valid.. Heteroscedasticity can be detected in several ways, among others, by using the glejser test. The glejser test is done by heading all independent variables to its absolute value. If there are independent variables significant to residual value then in the model there is heteroscedasticity.

d) Autocorrelation Test

The autocorrelation test aims to test whether in the regression model there is a correlation between the confounding error in the period to " $t$ " with the error in period "t-I" (previous).

The way to identify it is by looking at Durbin Watson (D-W):

1) If the $D-W$ value below -2 means there is a positive autocorrelation.

2) If the $\mathrm{D}-\mathrm{W}$ value between -2 to +2 means there is no autocorrelation.

3) If the $\mathrm{D}-\mathrm{W}$ value above +2 means there is autokorelasinegatif.

2. Multiple Regression

To find the relationship of $\mathrm{X} 1, \mathrm{X} 2$, with Ysecara together against $\mathrm{Y}$ using a double correlation formula. Multiple correlation formula:

Information:

$$
\mathrm{Y}=\beta+\beta 1 \mathrm{X} 1+\beta 2 \mathrm{X} 2+\mathrm{e}
$$

$\mathrm{Y}=$ Loyalty

$\beta=$ Constants

$\beta 1 \mathrm{X} 1=$ Price

$\beta 2 \mathrm{X} 2=$ Trust

$\mathrm{e}=$ Error

If research in the form of data about respondents perception about the variables used in this study are presented in the form of a questionnaire (quesioner). And secondary data obtained through supporting data obtained from the company in the form of documentation data relating to research variables. Instrumentation of data collection using interview and questionnaire.

Further questionnaires prepared are tested for feasibility through validity and reliability testing as follows:

a. Validity test

1. The purpose of testing Validity

Validity testing is done to test the extent to which the accuracy or correctness of an instrument as a measurement tool research variables. If the instrument is valid / true then the measurement result will likely be true.

2. Statistical formula for Validity Testing

$$
=\frac{\mathrm{n} \sum \mathrm{xy}-\left(\sum \mathrm{x}\right)\left(\sum \mathrm{y}\right)}{\sqrt{\left\{\mathrm{n} \sum_{\mathrm{x}} 2-(\mathrm{nx})^{2}\right\}}\left\{\mathrm{n} \sum_{\mathrm{y}} 2-\left(\sum \mathrm{y}\right)^{2}\right\}}
$$

Information:

$\mathrm{r}=$ Correlation coefficient between variable $(\mathrm{X})$ and variable $(\mathrm{Y})$

$\mathrm{n}=$ Number of observation pairs

$\mathrm{x}=$ Instrument item scores of the independent variables

$\mathrm{y}=$ Instrument item scores of the dependent variables 
The steps of validity testing performed include:

a. Correlates the scores of a questionnaire number with the total sector of all items

b. Determine whether or not valid data with the following criteria:

Criteria testing instrument reliability in this study are as follows:

c) If sig 2 tailed $<\alpha 0.05$ then the instrument grain is valid.

d) If sig 2 tailed $>\alpha 0.05$ then the instrument grain is invalid and must be removed.

b. Realibility Test

1. The purpose of testing reliability

Reliability testing is done to determine whether or not reliable research instruments that have been made. Reliable means the instrument can be used to measure the same object, will produce the same data. In this study, reliability calculations were performed with Cronbach Alpha tatistiks.

2. The statistical formula for realibity testing

The formula used in this research is:

$$
r=\left\{\frac{k}{(k-1)}\right\}\left[\frac{\sum \sigma \mathrm{b}^{2}}{\sigma 1^{2}}\right]
$$

Information:

$\mathrm{r}=$ Instrument Reliability

$\mathrm{k}=$ Number of questions

$\sum \sigma \mathrm{b}^{2}=$ Total variance of the item

$\sigma 1^{2}=$ Total variance

3. Criteria Testing Instrument Realibility

Criteria for instrument reliability testing are as follows:

c. If the value of the reliability coefficient $>0.60$ then the instrument has good reliability.

d. If the coefficient value realibiltas $<0.60$ then the instrument has a less good realibilitas.

Technique used in this research is quantitative data analysis, that is test and analyze data and then draw conclusion from the test.

1. Classic Assumption Test

Azuar Juliandi, Dkk (2015, p 160) classical assumption test of multiple regression aims to analyze whether the regression model used in the study is the best model. The requirements of the classical assumption test include, normality test, multicolinearity test, heterokedastity, and autocorrelation test.

a) Test Data Normality

Normality test data is done to see that a data distribution is normal or not. Test normality of data is done by using the way that Kolmogrov-Smirnov used to determine the normal or not the data. Data is normal, if the Kolmogrov-Smirnov value is insignificant (Asymp, sig (2-tailed) $>\alpha 0.05$ ).

b) Test of Multicolonierity

This multicolonierity test is intended to find out whether there is a perfect intercorrelation between some of the independent variables used in the model. Multicolonierity occurs when there is a linear relationship between the independent variables involved in the model. If there is a high degree of multicoloniality, standard error regression coefficients will be greater and result in confidence interval for parameter estimation widened, thus open the possibility of error, accept the wrong hypothesis.

Classical assumption assays multikolonieritas can be executed by way of regressing the model of analysis and test the collation between independent variables by using variance inflation factor (VIF). The limit of the VIF is 10 and the tolerancevalue value is 0.1 . If the VIF value is greater than 10 and the tolerance value of cevalue is less than 0.1 then multi colonierity occurs. 
c) Heteroscedasticity Test

Heteroscedasticity occurs when there is no standard deviation of the value of the dependent variable on each independent variable. If there are symptoms of heteroskedastisitas will cause the variation coefficient regression becomes minimum and confidence interval widen so that statistically significant test results are no longer valid. Heteroscedasticity can be detected in several ways, among others, by using the glejser test. The glejser test is done by heading all independent variables to its absolute value. If there are independent variables significant to residual value then in the model there is heteroscedasticity.

d) Autocorrelation Test

The autocorrelation test aims to test whether in the regression model there is a correlation between the confounding error in the period to " $t$ " with the error in period "t-I" (previous).

The way to identify it is by looking at Durbin Watson (D-W):

i. If the $\mathrm{D}-\mathrm{W}$ value below -2 means there is a positive autocorrelation.

ii. If the $\mathrm{D}-\mathrm{W}$ value between -2 to +2 means there is no autocorrelation.

iii. If the $\mathrm{D}-\mathrm{W}$ value above +2 means there is autokorelasinegatif.

2. Multiple Regression

To find the relationship of X1, X2, with Ysecara together against $\mathrm{Y}$ using a double correlation formula. Multiple correlation formula:

Information:

$$
\mathrm{Y}=\beta+\beta 1 \mathrm{X} 1+\beta 2 \mathrm{X} 2+\mathrm{e}
$$

$\mathrm{Y}=$ Loyalty

$\beta=$ Constants

$\beta 1 \mathrm{X} 1=$ Price

$\beta 2 \mathrm{X} 2=$ Trust

$\mathrm{e}=$ Error

\section{DISCUSSION}

Data analysis in this study aims to analyze data derived from data that has been described from previous data based on research instruments that have been validated and have a high level of reliability (reliable). The data analyzed starting from the assumptions used for a particular statistic by doing hypothesis testing for the conclusion, which is summarized in the test below:

1. Multiple Linear Regression

Results of processing using SPSS data on multiple regression analysis about the influence of Price (X1) and Location (X2) on Purchasing Decision (Y) House at PT. Wiratama Group, it can be seen in the table as a beri

Table 1

Multiple Value Regression

Coefficients $^{\mathrm{a}}$

\begin{tabular}{|c|c|c|c|c|c|}
\hline \multirow{2}{*}{ Model } & \multicolumn{2}{|c|}{ Unstandardized Coefficients } & $\begin{array}{c}\text { Standardized } \\
\text { Coefficients }\end{array}$ & \multirow{2}{*}{$\mathrm{t}$} & \multirow{2}{*}{ Sig. } \\
\cline { 2 - 5 } & $\mathrm{B}$ & Std. Error & Beta & &, 019 \\
\hline (Constant) & 8,525 & 3,568 &, 411 & 4,263 &, 000 \\
Harga (X1) &, 489 &, 115 &, 383 & 3,968 &, 000 \\
Lokasi (X2) &, 319 &, 080 & & \\
\hline
\end{tabular}

a. Dependent Variable: Purchase Decision

Source: Results of SPSS Data Processing (processed), 2018 
Based on the data of the above coefficients table (in the Unstandardized Coefficients column) we can see the multiple regression equations for the two predictors in Brand (X1) and Price (X2) variables are:

$$
\mathrm{Y}=\alpha+\mathrm{b} 1 \mathrm{X} 1+\mathrm{b} 2 \mathrm{X}+\mathrm{e}
$$

Then obtained value $\mathrm{Y}=8,525+0,489 \mathrm{X} 1+0,319 \mathrm{X} 2$

This acquisition of the equation above shows that all free variables Price (X1) and Location (X2) have positive coefficient value, with the meaning that all independent variables in this study have relationship and direct influence to variable Y (Purchase Decision), with assumption that the coefficient of variable Price (X1) gives a value of 0.489 which means that if the price is done well with the assumption of other independent variables fixed, then consumer purchasing decisions will increase. So also with the coefficient of Location (X2) gives a value of 0.319 which means that if the location of housing PT. Wiratama Group can be well maintained, assuming the value of other variables remains, then the consumer purchase decision variable will also increase.

\section{Use Classic Assumptions}

\section{Normality}

\section{Table 2}

Test of Normality Kolmogorov - Smirnov

One-Sample Kolmogorov-Smirnov Test

\begin{tabular}{|ll|l|}
\hline & & $\begin{array}{l}\text { Unstandardize } \\
\text { d Residual }\end{array}$ \\
\hline $\mathrm{N}$ & & 100 \\
Normal Parameters $^{\mathrm{a}}$ & Mean & .0000000 \\
& Std. Deviation & 2.17410806 \\
Most Extreme Differences & Absolute & .074 \\
& Positive & .074 \\
& Negative & -.065 \\
Kolmogorov-Smirnov Z & & .736 \\
Asymp. Sig. (2-tailed) & & .651 \\
\hline
\end{tabular}

a. Test distribution is Normal.

\section{Sumber: Data Diolah SPSS, 2018}

From the results of data processing in the above table obtained the value of Kolmogorov Smirnov is 0.736 and significant at 0.651 which means significant value greater than 0.05 then the residual data is normally distributed. For more details can be seen in normal imageP-P of regression standardized residual in the picture below

Normal P-P Plot of Regression Standardized Residual

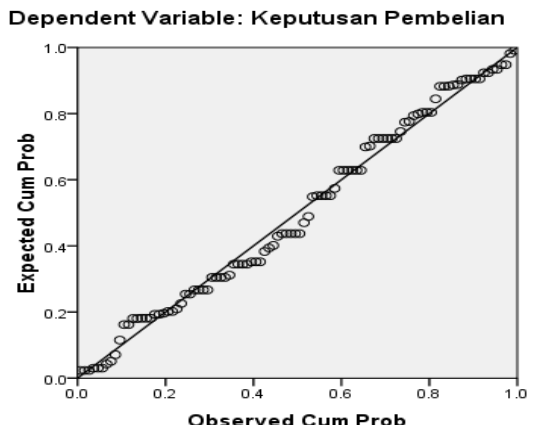

Picture 2

Standardized P-P Standardized Plasma Test 
The standardized P-P normality test image above indicates that the normality test of the regression model in this study has fulfilled the assumption previously stated, so the data in the regression model of this study tends to close to the line and it can be concluded that the normality test in this study variable is normally distributed.

\section{Multicolinearity}

Table. 3

Multicolinearity

\begin{tabular}{|l|c|l|}
\hline \multicolumn{1}{|c|}{ Model } & \multicolumn{2}{|l|}{ Collinearity Statistics } \\
\hline & Tolerance & VIF \\
\hline Price & $\cdot$ & 1.156 \\
Location & & \\
& 865 & 1.156 \\
\hline
\end{tabular}

Dependent Variable: Purchase Decision Sumber: Data Diolah SPSS, 2018

Based on the data table multicollinearity test above can be understood that the two independent variables namely Price (X1) and Location (X2) has a value of collinearity statistics VIF of 1.156. The value can be interpreted within the prescribed tolerance limits, where all variables close to the number 1 san VIF value smaller than 10. Thus it can be concluded that there is no multicollinearity in the independent variables in this study.

\section{Heterocedasticity}

Scatterplot

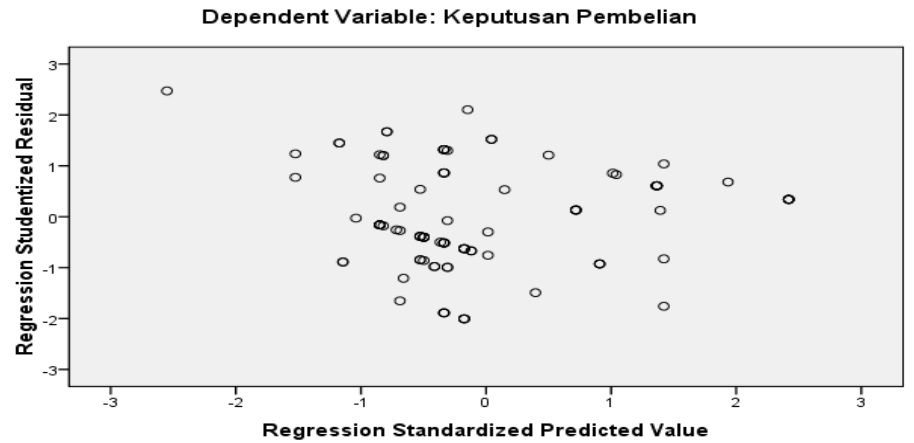

Picture. 3

Scatterplot Heterocedasticity Test

Based on the scatterplot image above can be seen that the variables in this study based on heterokedastisity test data can be interpreted that the absence of heteroskedasitas in variable research used. Because there is no clear pattern and spots spread above and below the number 0 on the $\mathrm{Y}$ axis. So it can be said heteroskedastisitas test on this research variable can be fulfilled. So the variable data used in this study can be used for further testing. 
Test of Research Hypothesis

Test $\mathbf{t}$

a) Brand Influence (X1) on Purchase Decision (Y) Dependent Variable: Purchase Decision

Table 4

Test $t$ (hypothesis 1)

zCoefficients $^{\mathrm{a}}$

\begin{tabular}{|c|c|c|c|c|c|c|}
\hline \multirow{2}{*}{\multicolumn{2}{|c|}{ Model }} & \multicolumn{2}{|c|}{$\begin{array}{l}\text { Unstandardized } \\
\text { Coefficients }\end{array}$} & \multirow{2}{*}{\begin{tabular}{|l|}
$\begin{array}{l}\text { Standardized } \\
\text { Coefficients }\end{array}$ \\
Beta \\
\end{tabular}} & \multirow{2}{*}{$\mathrm{t}$} & \multirow{2}{*}{ Sig. } \\
\hline & & B & Std. Error & & & \\
\hline 1 & $\begin{array}{l}\text { (Constant) } \\
\text { Price (X1) } \\
\text { Location (X2) }\end{array}$ & $\begin{array}{l}8,525 \\
, 489 \\
, 319\end{array}$ & $\begin{array}{l}3,568 \\
, 115 \\
, 080\end{array}$ & $\begin{array}{l}, 411 \\
, 383\end{array}$ & $\begin{array}{l}2,389 \\
4,263 \\
3,968\end{array}$ & $\begin{array}{l}, 019 \\
, 000 \\
, 000\end{array}$ \\
\hline
\end{tabular}

Source: Results of SPSS Data Processing (processed), 2018

Based on the data table t test above can be known the value of acquisition coefficients arithmetic $=$ $4,263 \mathrm{t}$ table $=1.660$. Based on the above test results the influence between the variable price $(\mathrm{X} 1)$ to the purchase decision (Y) obtained $t$ table of 1.660 (data $t$ tabel terlampir), and til value $t$ hitung of 4.263 with the meaning that $t$ hitung $>t$ tabel with significant $0.000<0,05$. Dari results can be concluded that Ho was rejected. It shows that there is a significant influence between Price variable (X1) on purchasing decision (Y) home purchase at PT. Wiratama Group.

b) Brand Influence (X1) on Purchase Decision (Y) Dependent Variable: Purchase Decision

Table 5

Test t (hypothesis 2)

\section{Coefficients $^{\mathrm{a}}$}



Source: Results of SPSS Data Processing (processed), 2018

Based on the data table t test above can be known the value of acquisition coefficients:

$\mathrm{t}$ count $=3.968$

$\mathrm{t}$ table $=1.660$

Based on the above test result, the influence between location variable (X2) to purchase decision (Y) is obtained $t$ table of 1,660 (data $t$ table terlampir), and by $t$ count of 3,968 with meaning that thitung > ttabel with significant of $0,000<0,05$.From the result can be concluded that Ho was rejected. It shows that there is a significant influence between Location variable (X2) on purchasing decision (Y) home purchase at PT. Wiratama Group. 
Test F

Table 6

Test F

\begin{tabular}{|c|c|c|c|c|c|c|}
\hline \multicolumn{7}{|c|}{ ANOVA $^{a}$} \\
\hline & & Sum of Squares & $\mathrm{df}$ & Mean Square & $\mathrm{F}$ & Sig. \\
\hline \multirow[t]{3}{*}{1} & Regression & 225,362 & 2 & 112,681 & 23,357 &, $000^{\mathrm{b}}$ \\
\hline & Residual & 467,948 & 97 & 4,824 & & \\
\hline & Total & 693,310 & 99 & & & \\
\hline
\end{tabular}

a. Dependent Variable: Keputusan Pembelian

b. Predictors: (Constant), Lokasi, Harga

Source: Results of SPSS Data Processing (processed), 2018

Based on the data table $f$ test with the above criteria obtained Fcount value of 23.357 Ftable value of 3.09 (data Ftabel attached) with a significant level of 0.05. Based on the value of the curve above can be understood that there is a significant influence between the variables Price (X1) and Location (X2) on Purchase Decision (Y) home at PT. Wiratama Group.

\section{Coefficient of Determination}

Testing coefficient of determination is done to determine the amount of nilaicoeficient which shows the amount of variation of the dependent variable that can be explained by the independent variable. In other words, the coefficient of determination is used to measure how far the independent variables are used in this study in explaining the dependent variable. Nilaikoefisien determination is determined by the value of $\mathrm{R}$ square as can be seen in the table below.

Table 7

Test F

Model Summary

\begin{tabular}{|l|l|l|l|l|}
\hline Model & $\mathrm{R}$ & R Square & $\begin{array}{l}\text { Adjusted } \\
\text { Square }\end{array}$ & $\begin{array}{l}\text { Std. Error of the } \\
\text { Estimate }\end{array}$ \\
\hline 1 &, $732^{\mathrm{a}}$ &, 536 &, 526 & 1,67035 \\
\hline
\end{tabular}

a. Predictors: (Constant), Location(X2), Price (X1)

b. Dependent Variable: Dependent Variable: Purchase Decision(Y)

\section{Source: Results of SPSS Data Processing (processed) 2018}

Based on the results of regression testing coefficient of determination model summary on the above table can know that the coefficient of determination ( $\mathrm{R}$ square) obtained in this study amounted to 0.536. This means that $53.60 \%$ of Purchase Decision variable can be explained by Price variable (X1) and Location (X2). While the rest of $46.40 \%$ can be explained by other free variables that are not included in this study. Discussion in this study will be translated through the hypothesis of research based on existing data analysis done earlier. For more details can be explained as follows:

\section{Price Influence (X1) on Purchase Decision (Y)}

The virtue of pricing can support a primary demand-oriented marketing strategy if the firm believes that cheaper prices can increase the number of users, the level of use or repurchase in the form or catagore of a particular product. Based on the results of Hypothesis 1 testing the influence of Price variable (X1) on Decision Purchase (Y) obtained ttable of 1.660 (data ttable attached), and obtained t count value of 4.263 with the meaning that thitung $>$ ttabel with significant value of $0.000<0.05$. From these results can be concluded that Ho is rejected. This shows that there is a significant influence between variable Price (X1) on purchasing decisions (Y) home purchase at PT. Wiratama Group. 


\section{Site Influence (X2) on Purchase Decision (Y)}

The primacy of location determination can support a primary demand-oriented marketing strategy if the firm believes that a strategic location can increase the number of users, the level of use or repurchase in a particular product form or category.Based on the results of Hypothesis 2 testing the influence of location variable (X2) on the purchase decision ) obtained ttable of 1.660 (data ttabelterlampir), and got tcount value of 3.968 with the meaning that thitung> ttabel with significant significance of 0.000 $<0,05$.From these results can be concluded that Ho is rejected. It shows that there is a significant influence between Location variable (X2) on purchasing decision (Y) home purchase at PT. Wiratama Group. The result of this research is in line with previous research by I Wayan Sastrawan (2015) "Analysis of Factors Influencing Selection of Business Location of Street Traders in Buleleng Buleleng Dissemination Point, Buleleng Regency". The result of this research is in line with the theory put forward by Buchari Alma (2003, p.105) suggests that "Choosing the right business location is crucial to the success and failure of the business in the future".

3. Influence of Price (X1) and Location (X2) on Purchase Decision (Y)

The virtue of pricing can support a primarily demand-oriented marketing strategy where companies believe that cheaper prices can increase the number of users, the level of use or repurchase in a particular product form or category, as well as for location determination for the company. Based on the data table $f$ test with the above criteria obtained Fcount value of 23.357 Ftable value of 3.09 (data Ftabel attached) with a significant level of 0.05 . Based on the value of the curve above can be understood that there is a significant influence between the variables Price (X1) and Location (X2) on Purchase Decision (Y) home at PT. Wiratama Group. The results of this study are in line with previous research by Syamsul Arifin (2013) "Influence of Products, Price, Location, Promotion, Facilities, and Service Against Iron Purchase Decision".

\section{CONCLUSION}

Based on the results of research and discussion on the Influence of Price and Location on Consumer Purchasing Decision House at PT. Wiratama Group Medan, can be concluded as follows:

1. Price (X1) has a positive and significant influence on the Purchase Decision obtained tcount of 4.263 with the provision of ttable value of 1.660 , with the meaning that thitung $>$ ttabel with significant value ebesar $0,000<0,05$. From these results it can be concluded that $\mathrm{H} 0$ is rejected in this study

2. Location (X2) has a positive and significant influence on the Purchase Decision obtained tcount of 3.968 with the provision of ttable value of 1.660 , with the meaning that thitung $>$ ttabel with significant value ebesar $0,000<0.05$. From these results it can be concluded that $\mathrm{H} 0$ is rejected in this study.

3. Variable Price (X1) and Location (X2) has a positive influence and simultaneously significant to the Purchase Decision (Y) obtained the value fhitungsebesar 23.257 while the ftabel of 3.09 with a significant level of $0.000<0.05$ from the results it can be concluded that $\mathrm{H} 0$ rejected in this research. Based on the coefficient of determination ( $\mathrm{R}$ square) obtained in this study amounted to 0.536. This implies that $53.60 \%$ of variables Purchase Decision (Y) can be explained by Price (X1) and Location (X2) variables

\section{REFERENCES}

Arianty Nel, Dkk. 2015. Marketing Management, Prime Publishing, Medan.

Daniel Moehar. 2002. Socio-Economic Research Methods, PT Bumi Perkasa, Jakarta.

Fahmi Irham. 2016. Consumer Behavior, Theory and Application, Alfabeta, Bandung.

Hair Lamb, Dkk. 2001. Book Marketing 2, Salemba Four, Jakarta.

Ikhsan Arfan, Dkk. 2014. Business Research Methodology for Accounting and Management, CV

Madenatera, Medan.

Juliandi Azuar, Irfan. 2013. Quantitative Research Methodology, For Science and Business, Citapustaka Media Perintis, Medan.

Lupiyoadi Rambat. 2013. Marketing Management Services, Salemba Four, Jakarta.

Subagyo Joko. 1997. Research Methods In Theory and Practice, PT Rineka Cipta, Jakarta.

Tjiptono Fandy Handra. 2012. Pemasaran Strategik, CV Andi Offset, Yogyakarta. 